\title{
Institutional Response to Trafficking in Human Beings in Spain: Are All Victims Equally Protected?
}

\author{
Carolina Villacampa $^{1}$ (D) Clàudia Torres ${ }^{1} \cdot$ Xavier Miranda $^{2}$
}

Accepted: 3 February 2022 / Published online: 10 February 2022

(c) The Author(s) 2022

\begin{abstract}
Trafficking in human beings is closely related to the cross-border movements of people and smuggling of migrants. However, the victim-centred regulatory approach to this reality internationally adopted places the protection of victims' human rights at the centre and demands an institutional response focused on their detection and protection. In order to determine whether this type of approach is being adopted in Spain, an online survey was conducted of 150 bodies, units and organisations that may have come into contact with such victims. The research results make it possible to determine how cases of trafficking are brought to light and which bodies are most effective at detecting them. They also offer information about the type of assistance offered to victims and the protection measures provided for under immigration law that are used depending on the type of trafficking suffered. These findings confirm that the institutional response to trafficking in human beings in Spain remains too focused on the trafficking of foreign women for sexual exploitation. Alternatives are proposed to overcome this highly biased response to the phenomenon.
\end{abstract}

Keywords Trafficking in human beings $\cdot$ Institutional response $\cdot$ Victim protection $\cdot$ Victim detection

\section{Introduction}

Trafficking in human beings (THB) is the process whereby a person is recruited, transferred, received and exploited in any type of legal or illegal economic activity by means of the threat or use of force, deception, abduction, sale, rental, exchange or abuse of a position of need of the person or of the trafficker's power. It is a phenomenon intrinsically linked to migration: the existence of individuals willing to be transferred from one place to another to be exploited upon arrival at their destination can be explained by the confluence of push factors driving them to leave their countries of origin, along with pull factors that draw them to the destination countries where they are ultimately exploited (Kara, 2009; Scarpa, 2008; UNODC, 2008; Zhang, 2007). There is a supply

Carolina Villacampa

carolina.villacampa@udl.cat

1 Department of Public Law, University of Lleida, Jaume II 73, 25001 Lleida, Spain

2 Department of Geography and Sociology, University of Lleida, Lleida, Spain 
of people at risk of severe exploitation because the process of economic globalisation based on a capitalist model has condemned many developing countries and their citizens to destitution. This, together with the lack of opportunities, the feminisation of poverty, the outbreak of armed conflicts, the existence of weak and corrupt state structures and, in some cases, the certain cultural practices, drives flows of people outside their countries of origin in search of a better life, which they can achieve in the destination countries with their incessant demand for cheap labour (Bales et al., 2009).

The relationship—not only phenomenological but also regulatory-between THB and migration was established with the adoption of the first international regulatory instrument to combat this reality, the 2000 United Nations Convention against Transnational Organized Crime, and its two supplementary protocols, the Protocol to Prevent, Suppress and Punish Trafficking in Persons, Especially Women and Children, and the Protocol against the Smuggling of Migrants by Land, Sea and Air. That initial close confluence of THB with illegal migration, which can still be seen in criminological analyses of the interaction between trafficking and states' migratory policies (Dwyer et al., 2011; van Meeteren \& Hiah, 2020; van Meeteren \& Wiering, 2019), gradually disappeared at the regulatory level as the former came to be considered an attack on human dignity of the first order requiring a victim-centred approach to human rights (Obokata, 2005, 2006), whilst control of migratory flows was addressed primarily by punishing offences. The aforementioned victim-centred approach seeks to take a holistic view of the problem and eradicate its causes, articulating the response to THB on the basis of what is known as the '3P policy', i.e. prevention, protection and prosecution, which prioritises protecting the victim and his or her welfare over prosecuting the crime. Whilst this policy was timidly established by the Protocol to Prevent, Suppress and Punish Trafficking in Persons, at the European regional level, it was developed above all by the 2005 Council of Europe Convention on Action against Trafficking in Human Beings and, to a lesser extent, Directive 2011/36/EU on preventing and combating trafficking in human beings and protecting its victims (Piotrowicz, 2018; Villacampa, 2012).

However, the way in which THB should be addressed from an international perspective may not always have been translated into how states deal with this reality. Spain was chosen as a case study to undertake this research precisely because its approach to THB has been found to be deficient, suffering from a double bias. First, a trafficking-centred vision has been adopted that has always kept it too closely linked to illegal migration. Unlike at the international regulatory level, where THB regulations have been separated from those for controlling migratory flows, in Spain this regulatory confusion has not disappeared over time. As a result of the inclusion of the offence of trafficking in human beings in the Criminal Code in 2010, these conducts ceased to be punished according to the offence of smuggling of migrants, ending the confusion between the two realities in terms of their prosecution. However, THB and smuggling of migrants have yet to be disassociated in relation to the protection of victims. This explains why some victim rights that should be recognised for all trafficking victims-including registration (the exclusive competence of specialised police bodies), assistance or the granting of a recovery and reflection period-are still unduly regulated under the Spanish Immigration Act, along with others, such as the granting of a residence and work permit on humanitarian grounds or the recognition of international protection, which are properly provided for under immigration law, as they can only be recognised for foreign victims. This confusion, it is said, has led to the invisibility of victims who do not fit the stereotype of an undocumented immigrant (Lara, 2017; Villacampa, 2011; Villacampa \& Torres, 2017). 
Second, the approach to THB in Spain has focused on raising awareness of and protecting victims of sex trafficking, largely neglecting victims of other forms of trafficking, such as for labour exploitation. In this regard, the situation in Spain is no different from that in other countries, as the preferred focus on THB for sexual exploitation has been criticised internationally (Home Office, 2007; Kaye et al., 2014; Kelly, 2005; Laczko, 2005; Tyldum $\&$ Brunovskis, 2005; Weitzer, 2012, 2014). However, the trend is even more pronounced in Spain, where trafficking for sexual exploitation is identified solely with prostitution (Defensor del Pueblo, 2012; GRETA, 2013, 2018; Iglesias, 2013; Maqueda, 2009; Villacampa, 2011; Villacampa \& Torres, 2017; Villanueva \& Fernández-Llébrez, 2019).

Beyond the aforementioned deficient national approximations to THB, implementing the internationally required victim-centred approach to it means placing the protection of victims, the recognition of their rights, at the centre of the institutional response. This, in turn, means detecting the people who suffer it as a necessary prerequisite to be able to afford them adequate protection (Obokata, 2005, 2006). Once they have been properly detected, their protection has to be guaranteed, both within the framework of the criminal process and, especially, outside it, which makes providing for and adequately implementing a comprehensive victim assistance programme essential for this type of approach. Hence, monitoring of the mechanisms through which cases of THB are detected and of the victim protection measures applied in a given country is crucial to determine whether it has substantively adopted this type of approach.

Despite being core elements for a victim-centred approach to THB, victim assistance and protection in relation to THB have not been addressed in much depth at the international level so far. The few existing studies are qualitative, and quantitative methodologies have only been used exceptionally (MIPROF, 2018). The existing qualitative studies focus on analysing issues closely related to victim detection (Farrell, 2014; Farrell \& Pfeffer, 2014; Kaye et al., 2014; Warria et al., 2015; Williamson et al., 2020), the different models for responding to trafficking, especially those based on collaboration and intersectoral action (DoCarmo, 2020; Erikson \& Larsson, 2020; Ricard-Guay \& Hanley, 2015; Timoshkina, 2020), those focusing on gender bias in victim assistance resources and services (Hacker et al., 2015; Ricard-Guay \& Hanley, 2020) and those aimed at exploring the relationship between such assistance and protection services and the current social, political and legislative context and dominant narrative at any given time (Jobe, 2020; Munro, 2020). Nor in Spain has the issue received much attention in the literature. The research conducted to date has mostly been based on qualitative approaches (Jiménez \& Tarancón, 2018; Torres \& Villacampa, 2017) and has generally focused on a specific manifestation of THB (Meneses et al., 2015; Villacampa \& Torres, 2017, 2018).

The present research was thus undertaken precisely to address THB victims' assistance and protection from a quantitative perspective, predominantly descriptive, given that the scholarly literature has criticised the lack of robustness of the quantitative data on THB in general (Cockbain \& Bowers, 2019; Cockbain et al., 2018; Gozdziak \& Bump, 2008) so that approaches could also be compared depending on the type of THB in question. The main objective is to analyse from a quantitative perspective the institutional approach to protection of THB victims in Spain as a case study of what may be happening in other neighbour countries with deficient approaches to this reality. It does this, first, by studying how cases of THB come to light in a given period and identifying the most efficient bodies with regard to their detection and, second, by analysing the protection mechanisms applied to THB victims, both to assist them and with regard to their continued stay in Spanish territory. The study period was limited to 2017 and 2018 because the Spanish government had already provided the data up to 2016 to the European Commission for the purposes of 
preparing the most recent European statistical report on the issue when this research was undertaken (European Commission-Migration \& Home Affairs, 2018). Additionally, it was easier for the surveyed organisations to provide quantitative data on a short period of time that was still relatively recent when the data were collected.

\section{Method}

In order to collect mostly descriptive, but also inferential, quantitative data on the institutional approach to THB, a survey was conducted of various bodies, units and organisations (BUOs) that might have come into contact with victims of the process in 2 years prior to the study. To this end, a database was developed with 757 BUOs that might have detected victims in 2017 or 2018. It was developed using a purposive sampling system based on earlier samples of BUOs available as a result of previous research conducted by members of the research team showing certain entities that had detected THB victims (Villacampa \& Torres, 2017, 2018, 2020). The original sample was composed by first-line criminal justice professionals (amongst them, specialised and non-specialised police officers, public prosecutors and lawyers), victim service providers (victim assistance offices, administrative units dealing with crime victims, migrants and women and NGOs assisting victims), social services (mostly addressed to immigrants, women and minors) and education organizations. It was supplemented by means of a web crawl, a web search for further entities, that made it possible to add bodies that were not in the initial databases, including some victim service providers and certain agencies belonging to state law enforcement bodies, as well as unions, labour inspectors and healthcare professionals.

Next, the 757 members of the invited sample were contacted by phone or e-mail to explain the content of the research and subsequently sent the developed online questionnaire. The data collection instrument, which was approved by the University of Lleida Research Ethics Committee, consisted of a questionnaire developed with Google Forms. Its design, in particular with regard to the protection mechanisms applied to THB victims, was based on the information contained in the recent statistical reports published in Europe (European Commission-Migration \& Home Affairs, 2018; Eurostat, 2015); questions were then added about the surveyed BUO.

The questionnaire had three parts. The first one contained general questions about the characteristics of the BUO, referring to its area of action, whether it was considered a body specialised in THB, whether it had received training on THB and, if so, on which aspects thereof and whether it had detected THB victims in the period under study. The second part, completed only by those bodies that had detected victims, consisted of questions about the type of assistance they had provided and which victims it was targeted at. Finally, in the third part of the questionnaire, the bodies were asked to complete up to 4 specific sections depending on whether they had detected THB victims for sexual, labour, criminal or other forms of exploitation (including forced marriages, organ or blood donations and forced pregnancies). For each type of trafficking detected, they were asked about the frequency with which the victims are granted the recovery and reflection period or an exceptional residence permit on humanitarian grounds, as well as the frequency with which they apply for and are granted refugee status or subsidiary protection.

Of the 757 BUOs in the invited sample, the real sample ultimately consisted of 150 BUOs, namely, those that responded to the survey. The geographical distribution of the BUOs is shown in Fig. 1. BUOs located in Catalonia are more prevalent in the real 


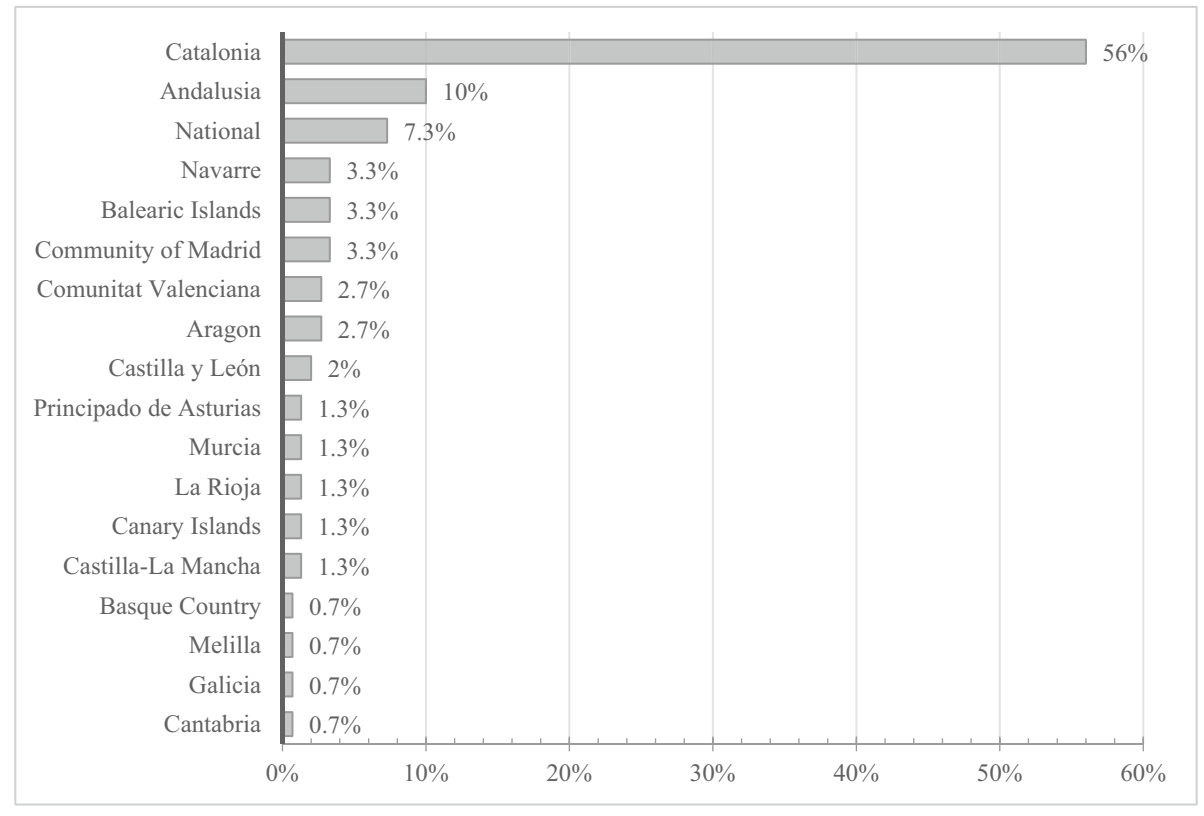

Fig. 1 Autonomous community in which the surveyed BUO operates

sample because, being the research conducted by a public Catalan University, those operating in Catalonia were predominantly addressed. This was specially the case for the victim service providers, whose activity is decentralised and coordinated by the Autonomous Communities in Spain.

Most of the BUOs were dedicated to assisting THB victims $(n=52)$, gender and domestic violence victims $(n=41)$ or victims in general $(n=37)$ or were police BUOs $(n=36)$ or immigrant assistance bodies $(n=27)$ (see Fig. 2$)$.

Of the 150 completed questionnaires, $44 \%(n=66)$ were submitted by bodies that had detected victims and thus completed the entire questionnaire, including all or some of the 4 sections comprising the third part. In contrast, 51\% $(n=77)$ of the BUOs from the final sample indicated they had not detected victims, whilst in 5\% $(n=7)$ of the cases, the person completing the questionnaire on behalf of the body indicated they did not know whether it had detected victims. In both of these cases, these bodies completed only the first part of the online form.

Most of the 66 BUOs that did provide information about THB victimisation completed the section of the questionnaire on the detection of victims of THB for sexual exploitation $(n=62)$, followed by the detection of victims of THB for labour exploitation $(n=31)$, criminal exploitation $(n=17)$ and other forms of exploitation $(n=14)$. Although this is not a large sample of BUOs from a quantitative point of view, given the difficulty of identifying bodies that may have come into contact with THB victims, the number of completed questionnaires is not insignificant. Additionally, the surveyed BUOs provided information about all the victims detected in the 2-year study period. The data provided thus refer to a number of people far greater than the number of questionnaires completed. 


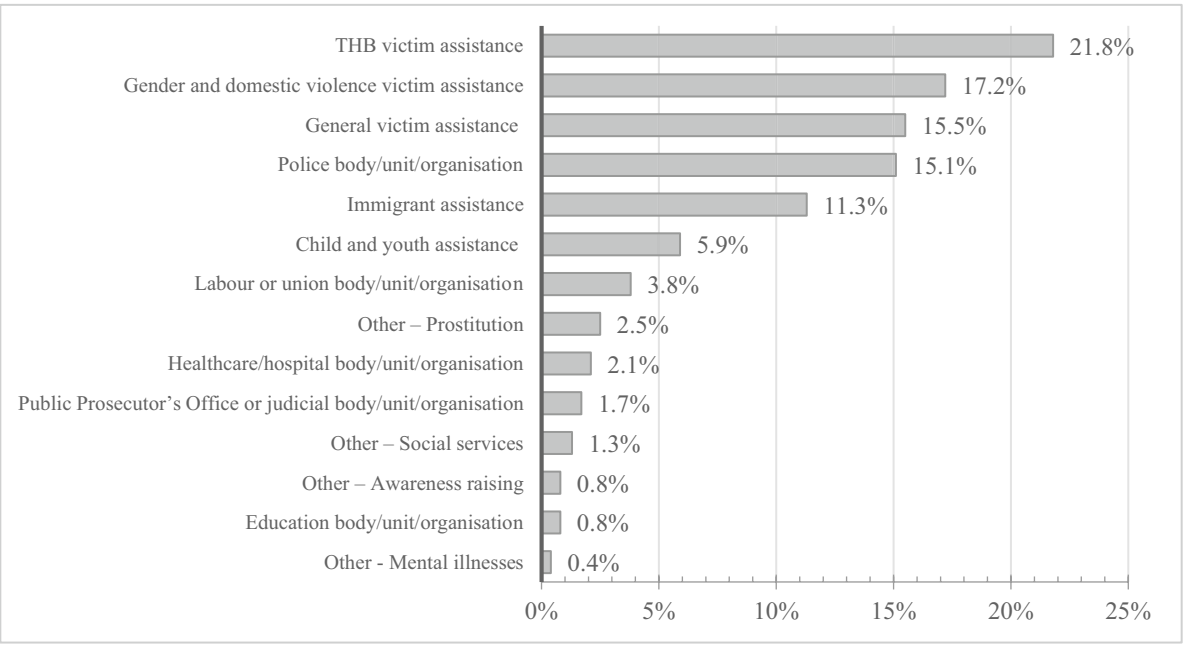

Fig. 2 Area of action of the surveyed BUO

\section{Results}

\section{Mechanisms Through Which Cases of THB Are Brought to Light: Which Bodies Are Most Effective at Victim Detection?}

According to the data provided by the surveyed BUOs, 7,448 victims were detected in the study period. The variables gender, age and type of THB to which they were subjected were known for $95.95 \%$ of them $(n=7.146)$; they were not known for the remaining $4.05 \%$ of the detected victims $(n=302)$. This is a far higher number of people than the number of victims $(n=458)$ formally identified and registered in the same 2-year period by the Intelligence Centre for Counterterrorism and Organised Crime (CITCO), the Spanish Interior Ministry body responsible for centralising the collection of police data on registered victims.

This gap between the number of detected and identified victims has also been reported at the international level (ILO, 2017; UNODC, 2018) and supports the opinion of those who argue that the THB surfacing in the system may only be the tip of the iceberg (Aronowitz, 2009; Kangaspunta, 2007). However, some of Spain's neighbours, such as the UK or the Netherlands, have managed to register many more victims than Spain, not only in absolute terms, but also as proportion of population (European Commission-Migration \& Home Affairs, 2018, 2020), reporting a number of victims far less removed from the number of detected victims than here. These countries have proven to be much more efficient than Spain in detecting victims. The great difference in Spain between the number of victims detected and those formally identified shows that it were able to narrow the gap between the two numbers; it would gain in efficiency in registering victims, enabling a larger portion of THB cases to come to light. Hence, the great importance of knowing how the cases detected in this study came to light and which BUOs were most effective at detecting them.

To this end, the 66 surveyed BUOs that detected victims were asked how they had done it. Most of them reported that the cases came to light because the body itself undertook 
some type of action to detect them $(n=43,34 \%)$ or because they had been referred to them by other BUOs $(n=43,34 \%)$. A smaller number of cases surfaced because the victim sought help from the BUO $(n=29,24 \%)$. Almost never did people around them report what was happening (Fig. 3). These findings are consistent with those of previous studies conducted in other European countries (MIPROF, 2018).

Proactive action by the BUOs is what seems to have the greatest impact on the detection of THB victims, either because they detect them directly through their search actions or because they are referred cases by other BUOs. Only $32 \%$ of cases were detected because someone reported them. In light of this finding, it is of interest to determine the extent to which the activities of these BUOs were oriented towards THB, whether they had received training in this area and the extent to which these points explain their success in detecting victims.

A comparison of the variable referring to the BUOs' area of activity with that referring to the detection of victims shows that the BUOs that detected the most victims were those that reported they were dedicated to THB victim assistance $(n=43)$, followed by those focused on assisting victims of gender and domestic violence $(n=22)$, victims in general $(n=18)$ and immigrants $(n=16)$. Police bodies ranked fifth $(n=12)$.

To assess the level of specialisation in the matter, the BUOs were specifically asked whether they considered themselves specialised in THB. Even though the sample was purposive, 25 BUOs did not answer this question. Of those that did, 44.8\% $(n=56)$ responded affirmatively, whilst the majority either responded negatively $(52.8 \%, n=66)$ or indicated that they did not know $(2.7 \%, n=3)$.

Although they did not for the most part consider themselves to be specialised in THB, they did more generally report having received training on various manifestations of THB other than THB for sexual exploitation. Of the 150 surveyed BUOs, 23 did not answer the question on whether they had received training on THB for labour, criminal or other forms of exploitation. Those that did answer it mostly reported that they had received such training $(59.84 \%, n=76)$, compared to those reporting they had not received training $(37.8 \%$, $n=48)$ or stating they did not know $(2.36 \%, n=3)$. When asked about which specific aspects of THB they had received training on, a question that only 76 of the 150 surveyed

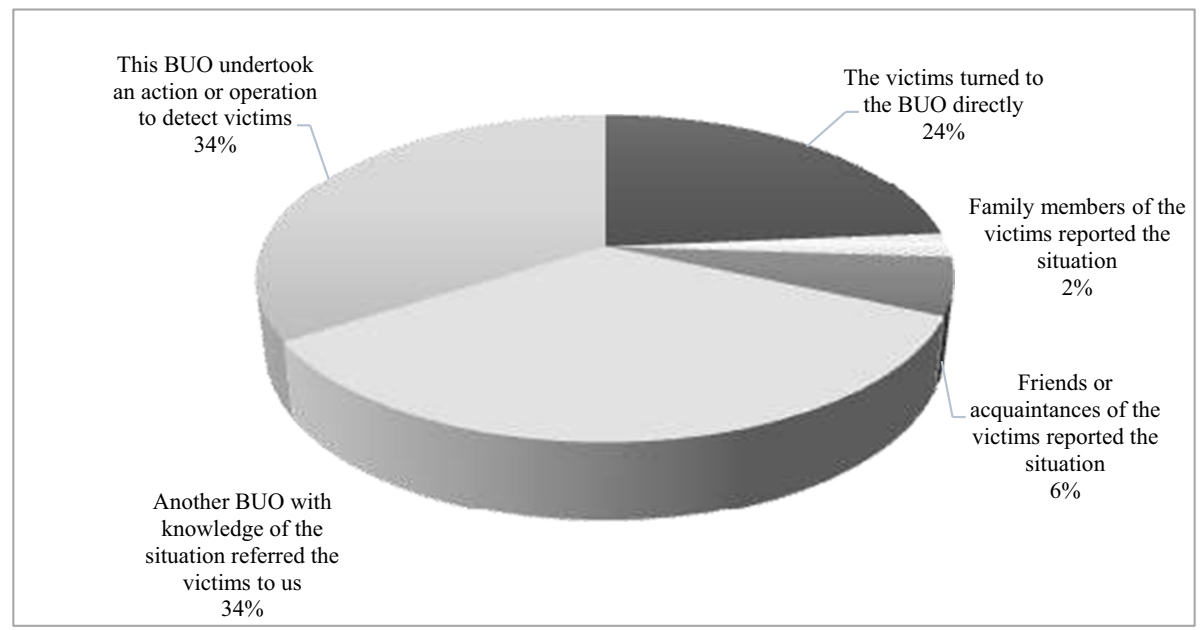

Fig. 3 Ways in which victims were detected 
BUOs answered, they indicated that it primarily covered victim assistance and protection $(n=24)$, victim identification $(n=22)$ and criminal prosecution of THB $(n=14)$. Of the 3 Ps that make up the strategy for the institutional approach to THB at the international level, the training was most focused on victim protection and criminal prosecution; prevention of victimisation by THB at different levels, collaboration between the various agents that deal with it and the collection of data on the phenomenon were not training priorities (Fig. 4).

As all the BUOs in the final sample were asked about their degree of specialisation and training on THB issues whether or not they had detected THB victims, a bivariate analysis was conducted to determine the relationship between the variable consisting of identifying victims and those related to the degree of specialisation and training received in the field of THB. In all cases, the bivariate association yielded statistically significant results. The most effective bodies in terms of detecting victims of any type of THB in the studied 2 -year period were those that considered themselves specialised in the phenomenon $\left[\left(\chi^{2}\right.\right.$ $\left.(6, N=150)=63.290, \rho=0.000, \Phi_{\text {Cramer }}=0.459\right]$ and those that had received training on the subject $\left[\left(\chi^{2}(6, N=150)=49.11, \rho=0.000, \Phi_{\text {Cramer }}=0.405\right]\right.$. Specifically, those that had received training on aspects such as victim assistance and protection and victim identification were more effective $\left[\left(\chi 2(16, N=150)=60.53, \rho=0.000, \Phi_{\text {Cramer }}=0.449\right]\right.$. This confirms what previous empirical research has shown, insofar as professionals' ability to detect THB victims increases when their level of specialisation and training are increased (Farrell, 2014; Farrell \& Pfeffer, 2014; Farrell et al., 2020; Kaye et al., 2014; Renzetti et al., 2015; Villacampa \& Torres, 2017, 2018; Warria et al., 2015; Williamson et al., 2020).

\section{Type of Assistance Provided to THB Victims}

The second specific aim of this research was to analyse the protection mechanisms applied to the detected THB victims. Aside from the protection measures that may be applied to victims in the context of criminal proceedings, the most important aspect when addressing victim protection is the assistance provided to them. Determining which types of assistance

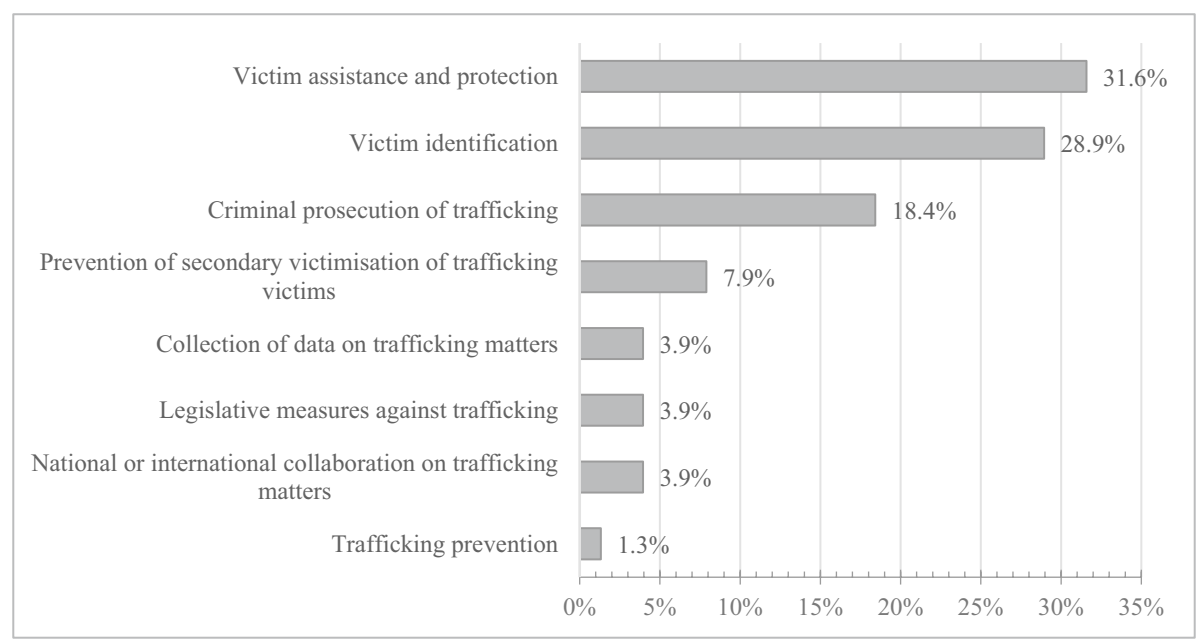

Fig. 4 THB-related issues on which the BUO has received training 
mechanisms are provided is thus essential to a study, such as this one, that aims to test the institutional approach to protection of THB victims.

To this end, the surveyed BUOs that reported having detected victims were asked about the types of protection measures they applied. They were told that they could choose more than one of the listed options, as well as add others. The most frequent responses were legal assistance (85.5\%), medical and psychological assistance (71\%) and accommodation (67.7\%) (Fig. 5). This group of the most commonly chosen options was followed by a second group, consisting of reintegration assistance and training/education. Finally, the least widespread actions had to do with job placement, return assistance and legal and emotional support. The main assistance provided was the most urgent kind, and measures aimed at educational or professional training for victims, their reintegration or even their assisted return were selected less frequently. These results only partially confirm the findings of the most recent statistics published at the European level, even if Spain did not provide data on this specific aspect, since, whilst medical and psychological assistance were the second most frequently chosen option, the most recurrent was accommodation (European Commission-Migration \& Home Affairs, 2018). Nor do they confirm the findings of previous European national studies, which point to the existence of longer-term victim assistance (MIPROF, 2018).

As for who the main recipients of the provided assistance are, the surveyed bodies' responses show that the protection measures were applied almost only to women $(89.4 \%$, $n=59$ ), with only $7.6 \%$ of the BUOs reporting having applied them to both men and women $(n=5)$, notwithstanding the $3 \%$ that said they did not know. These results are consistent with the gender breakdown of the detected trafficking victims, in which the percentage of women was much higher than that of men ( $96.11 \%$ women vs $3.89 \%$ men), as well as with the noted bias of the institutional response to THB in Spain, which is strongly focused on THB for sexual exploitation. This assistance provided almost exclusively to women victims of THB for sexual exploitation is reflected not only in the breakdown of the institutional assistance given to victims of the various forms of trafficking, but also in the allocation of care resources for the various manifestations of this reality and the groups

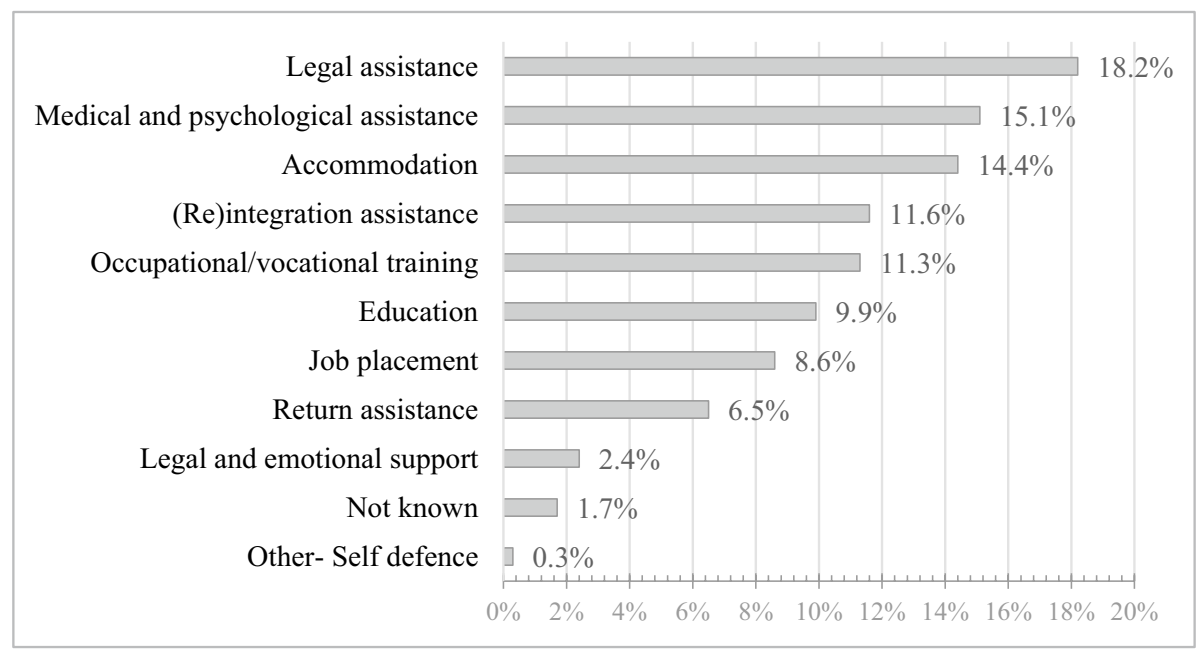

Fig. 5 Type of assistance provided to victims 
that they affect. With regard to these resources, priority also continues to be given to care for women victims of THB for sexual exploitation, and virtually no resources are allocated to assisting men (Torres \& Villacampa, 2017), a situation that has also been found in other countries (Hacker et al., 2015; Ricard-Guay \& Hanley, 2015, 2020). This situation is likewise unfortunately very widespread in Europe, where $75 \%$ of assisted THB victims are women (European Commission-Migration \& Home Affairs, 2018).

Minor victims of THB are also largely invisible and, in fact, not only in terms of the attention that their status as victims of this reality has merited and the consequent lack of their detection as such, as denounced in the literature (Weitzer, 2012), but also in the implementation of care resources. The first of these aspects was highlighted by the present research, insofar as it confirmed that, of the detected victims of known age, only 393 (5.5\%) were minors. Additionally, the surveyed BUOs scarcely knew the status of these minors. When asked whether they were mostly unaccompanied, $48.5 \%$ of the respondents declined to answer the question or said they did not know, compared to 19 BUOs (28.8\%) that indicated that they were not unaccompanied. Only 15 of the surveyed BUOs $(22.7 \%)$ indicated that they could be considered mainly unaccompanied minors, whereas the Spanish literature has highlighted the risk that such minors have of being subjected to trafficking situations (Castaño, 2020; Claro, 2019; García, 2010).

The invisibility of minor victims translates, again, not only to their lack of detection, but also to a failure to organise specific assistance resources for them. This assistance gap has already been highlighted in earlier research with professionals conducted in Spain (Jiménez \& Tarancón, 2018; Meneses et al., 2015; Torres \& Villacampa, 2017) and is confirmed by the present analysis. It has likewise been quantified at the European level, where, on average, only one-third of THB victims are minors, a figure that falls to $6 \%$ in the case of Spain (European Commission-Migration \& Home Affairs, 2018) and seems also to have decreased even in the EU to $23 \%$ of the victims according to the last published statistical report (European Commission-Migration \& Home Affairs, 2020). When the surveyed BUOs were asked which assistance measures they had applied to these victims (see Fig. 6), the most common response was the adoption of specific measures to assist and support minor victims $(n=18)$. However, the second most frequently chosen answer was that the respondent did not know whether these types of assistance measures had been adopted

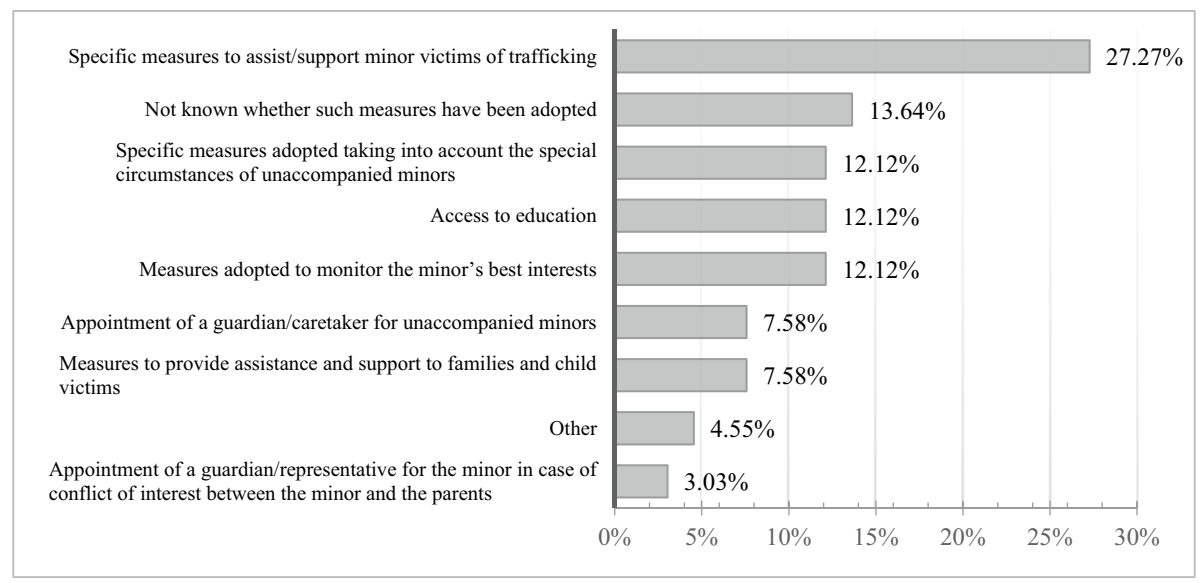

Fig. 6 Assistance measures adopted with minors 
$(n=9)$, revealing a lack of knowledge on the part of some of the surveyed professionals regarding the types of measures adopted with minors. Finally, measures aimed at meeting the minor's needs that go beyond immediate assistance-such as those specifically adopted taking into account the special circumstances of unaccompanied minors and those aimed at assessing the minor's best interest or ensuring his or her access to education-or those aimed at meeting the needs of his or her family were less commonly adopted. These results diverge from those obtained at the European level, which do not include data from Spain, in which such longer-term assistance measures are used more frequently and, in particular, where this lack of knowledge regarding the measures adopted is not found amongst professionals (European Commission-Migration \& Home Affairs, 2018).

\section{Implementation of Protection Measures for THB Victims in Immigration Matters}

In the context of a mostly descriptive quantitative analysis of assistance for THB victims, it is also pertinent to examine the level of implementation of victim protection measures that the Spanish legal system provides solely for foreign victims of trafficking who are not legal residents of Spain, which, even though they are provided for only for such victims, are nevertheless protection mechanisms. These mechanisms include the granting of a recovery and reflection period, of a period of temporary residence on humanitarian grounds and, finally, of refugee status or subsidiary protection.

To analyse these three issues, respondents that had detected victims of the four forms of THB analysed-for sexual, labour, criminal or other forms of exploitation-were asked how often each of these measures was granted. Given that these questions were asked for all four of the studied types of trafficking, the responses obtained make it possible not only to determine the extent to which these mechanisms are being used, but also to establish whether they are used differently depending on the type of trafficking.

The results show that the granting of a recovery and reflection period-which can be granted for 90 renewable days only to foreign victims without legal residency in Spain-is rarely used (see Fig. 7), confirming what previous studies conducted in other European countries have found (NRTHB, 2018). For all four forms of trafficking studied, such

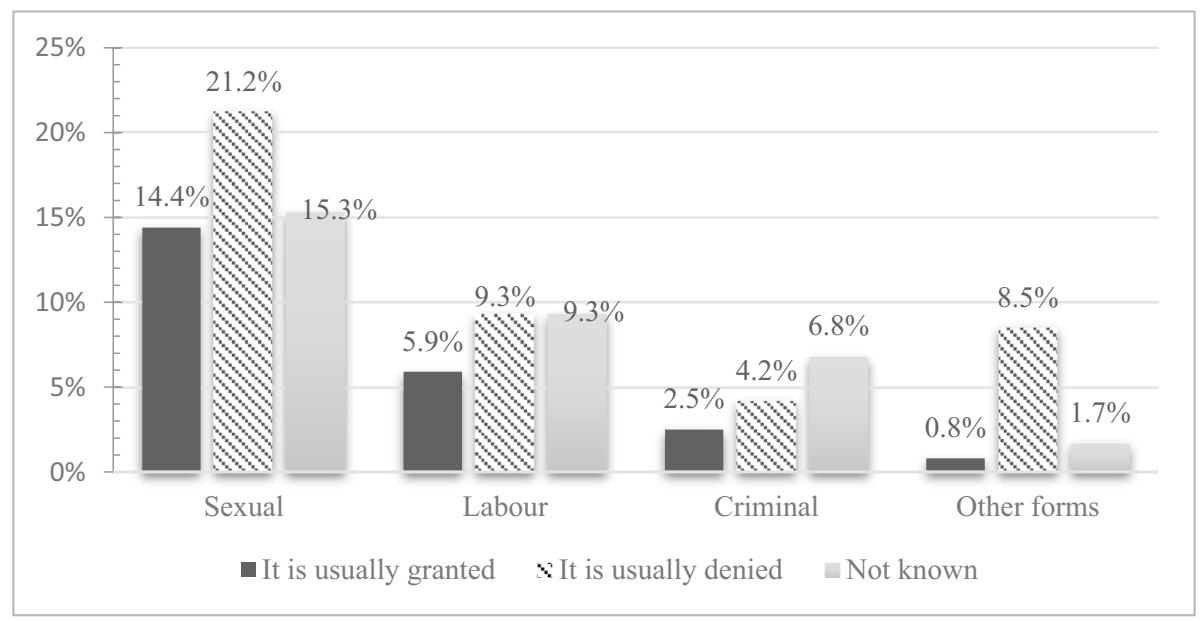

Fig. 7 Frequency with which the recovery and reflection period is granted by type of THB 
periods were more likely to be denied than bestowed. This is consistent with the data available to date on this protection mechanism in Spain. Those data show that few victims apply for this measure, that courts are reluctant to grant it and that in general they do so in ways closely linked to the victims' cooperation with law enforcement authorities (FGE, 2019; Lara, 2017; Torres \& Villacampa, 2017), even though Spain ranks third amongst European countries in the granting of this measure (European Commission-Migration \& Home Affairs, 2018).

However, the present research also reveals differences in the degree to which it is granted depending on the type of trafficking suffered. The percentage of BUOs who responded that it is usually conferred in cases of sex trafficking was clearly higher than that reporting that it was usually granted with other types of THB (Fig. 7). Although a comparison of the four types of THB analysed does not make it possible to conclude that the type of trafficking suffered is statistically significant in explaining the granting of this measure $\left[\left(\chi^{2}(6, N=118)=9.279, \rho=0.159, \Phi_{\text {Cramer }}=0.198\right]\right.$, the bivariate association with regard to whether it is issued when sex trafficking is compared to trafficking for labour $\left[\left(\chi^{2}(16, N=27)=32.866, \rho=0.008, \Phi_{\text {Cramer }}=0.552\right]\right.$ or criminal exploitation $[(\chi 2(12$, $\left.N=15)=27.768, \rho=0.006, \Phi_{\text {Cramer }}=0.786\right]$ is statistically significant. Furthermore, the respondents' lack of awareness of whether or not it is granted in cases of THB for labour or criminal exploitation confirms their scant knowledge of even the victim protection mechanisms implemented outside the context of THB for sexual exploitation.

The type of THB experienced by the victim thus has explanatory power with regard to the concession of this period, which benefits victims of THB for sexual exploitation more than other types of victims. However, it also has predictive value for explaining the granting of this period. A multinomial logistic regression was carried out with the type of THB as the dependent variable, using THB for sexual exploitation as a model, considering as factors the granting of a recovery and reflection period, the acceptance of an exceptional residence permit on humanitarian grounds and the granting of international protection. The model's statistics show that it has a good ability to discriminate between types of THB [-2 Log Likelihood $=109.5, \chi 2(36)=78.59, p<0.000$; Nagelkerke $\left.\left.R^{2}=0.876\right)\right]$. According to this regression, the recovery and reflection period is 62 times less likely to be bestowed to victims of THB for labour exploitation than to those of THB for sexual exploitation $\left(b=4.128\right.$, Wald $\left.\chi_{(1)}^{2}=1.687, p=0.194\right)$.

These results for the granting of the recovery and reflection period confirm the institutional bias in the approach to THB in the case of Spain that results in the greater visibility of victims of only one type of THB, i.e. THB for sexual exploitation-who are mostly women - to the detriment of victims of other types of THB. This finding is further supported by the fact that although, on average, in Europe, $77 \%$ of victims to whom this period is granted are women, in Spain this percentage climbs to $87 \%$ (European CommissionMigration \& Home Affairs, 2018).

Second, once the recovery and reflection period has ended, THB victims may be granted a residence and work permit for exceptional circumstances for up to 5 years. Although, theoretically, it may be granted both on humanitarian grounds and for cooperation with the authorities, in practice the courts only confer it when there is evidence of such cooperation (CGPJ, 2015), as has also been found in other Western countries (Ricard-Guay \& Hanley, 2020). Once again, in relation to this second protection measure, despite the infrequency with which it is bestowed in general, differences can still be found depending on the type of trafficking in question. Although the most frequent response was that it is not usually granted, the affirmative responses were concentrated in cases of THB for sexual exploitation (Fig. 8). 


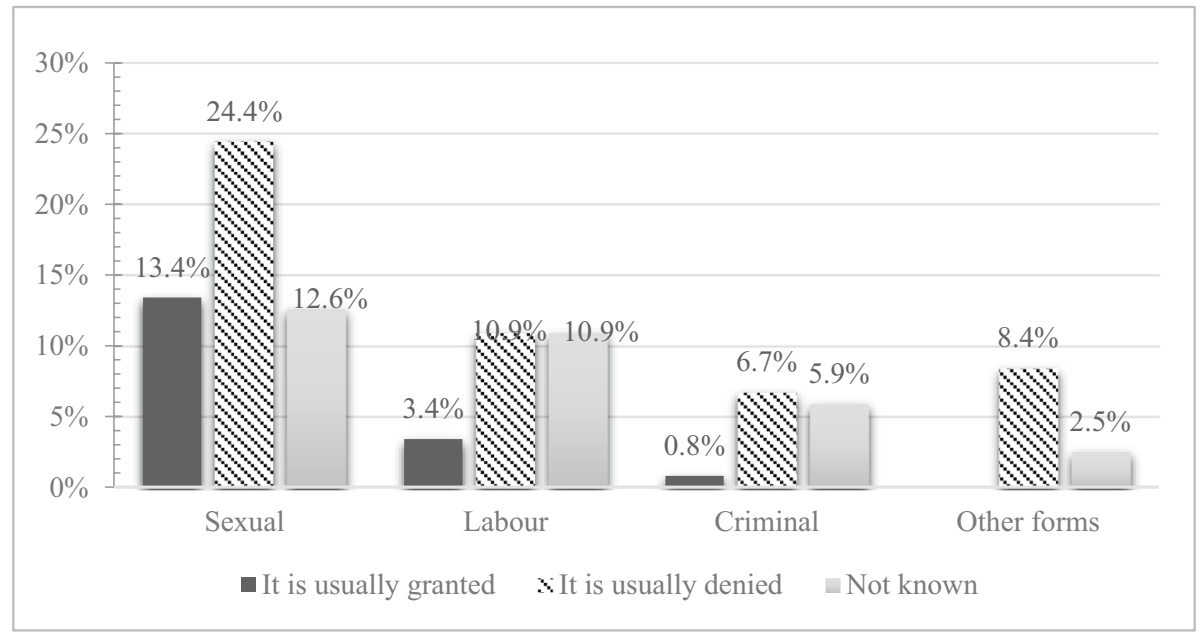

Fig. 8 Frequency with which the exceptional residence permit on humanitarian grounds is granted by type of THB

The cross-tab comparing the frequency with which it is granted in cases of THB for sexual exploitation versus cases of THB for labour $[(\chi 2(16, N=28)=41.776, \rho=0.000$, $\left.\Phi_{\text {Cramer }}=0.611\right]$ or criminal $\left[\left(\chi 2(12, N=15)=21.000, \rho=0.050, \Phi_{\text {Cramer }}=0.683\right]\right.$ exploitation shows that the type of trafficking suffered is relevant to explaining whether or not the measure is adopted, even though the comparison of all four forms of THB analysed is not significant $\left[\left(\chi 2(6, N=119)=11.860, \rho=0.065, \Phi_{\text {Cramer }}=0.223\right]\right.$. The institutional bias in the approach to trafficking can be confirmed in this case, too, with its focus on making victims of THB for sexual exploitation more visible. The bias is even more pronounced in this case than in the granting of the recovery and reflection period, as whilst on average in Europe 59\% of the beneficiaries of this measure are women, in Spain, this share is $90 \%$ (European Commission-Migration \& Home Affairs, 2018).

Finally, the same bias towards sex trafficking was found in relation to the third protection measure that can be adopted for THB victims under immigration law, namely, international protection, whether through the granting of refugee status or subsidiary protection to the victim, depending on the case. This should be the preferred course of action for victims to remain legally in Spain (CGPJ, 2015). However, both in Spain and internationally (Jobe, 2020), the scant use made of this protection measure has already been denounced (Castaño, 2019, 2020; Claro, 2019; Santos, 2019). The present research numerically confirms the limited use of the international protection mechanism for THB victims (see Fig. 9). It further shows that, once again, the only cases in which it is granted are those involving THB for sexual exploitation. Although the comparison between the four types of studied THB was not statistically significant $[(\chi 2(6, N=120)=7.695, \rho=0.261$, $\left.\Phi_{\text {Cramer }}=0.179\right]$, the bivariate association between THB for sexual exploitation and THB for labour $\left[\left(\chi 2(9, N=29)=49.760, \rho=0.000, \Phi_{\text {Cramer }}=0.756\right]\right.$ or criminal exploitation $\left[\left(\chi^{2}(4, N=16)=9.600, \rho=0.048, \Phi_{\text {Cramer }}=0.548\right]\right.$ was statistically significant in this case, too. The type of trafficking suffered thus also has explanatory power for the application of international protection mechanisms to victims, which benefit victims of sex trafficking to a greater extent. It moreover has predictive value, as the logistic regression performed shows that victims of THB for labour exploitation are 3.5 times more likely than those 


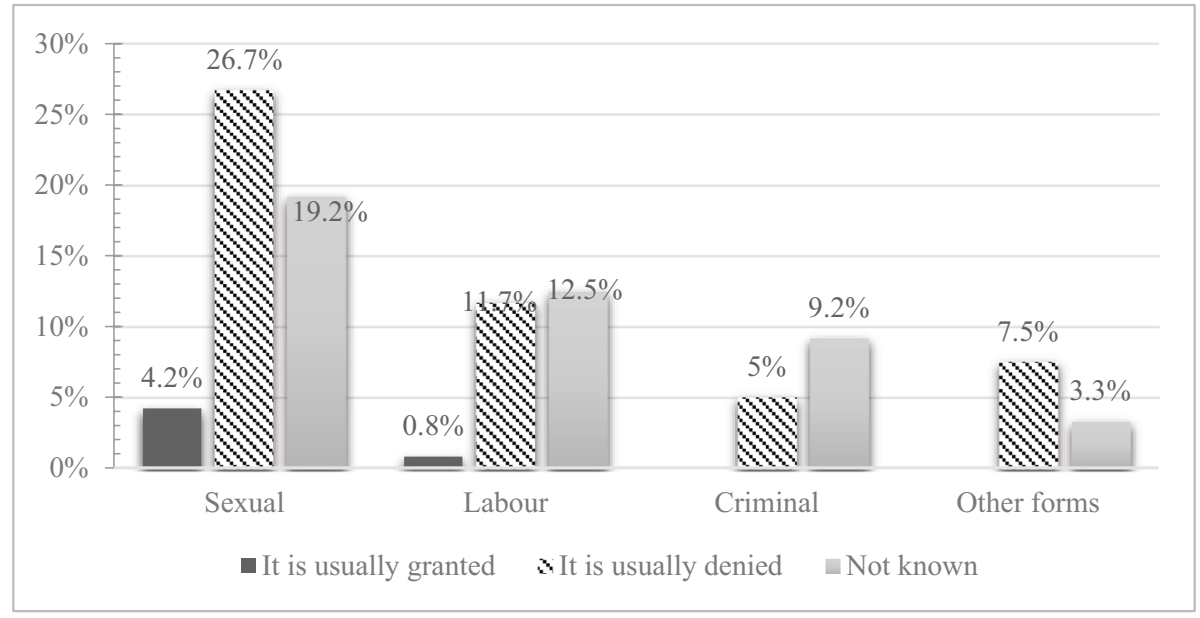

Fig. 9 Frequency with which refugee status/subsidiary protection is granted by type of THB

of sex trafficking to have their application for refugee status denied $\left(b=1.267\right.$, Wald $\chi^{2}$ (1) $=0.159, p=690$ ).

Additionally, not only are victims of THB for sexual exploitation recognised more often and, thus, more likely to be granted refugee status, they are also the ones to apply for it most often (see Fig. 10), which is statistically confirmed when the four types of analysed trafficking are compared $\left[\left(\chi 2(6, N=120)=13.172, \rho=0.040, \Phi_{\text {Cramer }}=0.234\right]\right.$. The higher rate of application by victims of THB for sexual exploitation compared to those for labour exploitation may be due to the fact that, according to the literature, the latter types of victims have more difficulty in recognising themselves as such (Rijken, 2011; Skrivankova, 2010; Van Meeteren \& Hiah, 2020; Van Meeteren \& Wiering, 2019). However, in a context such as Spain's, in which so much prominence has been given to sex trafficking, it may also be due to a lack of confidence on the part of these victims that they will be recognised as such.

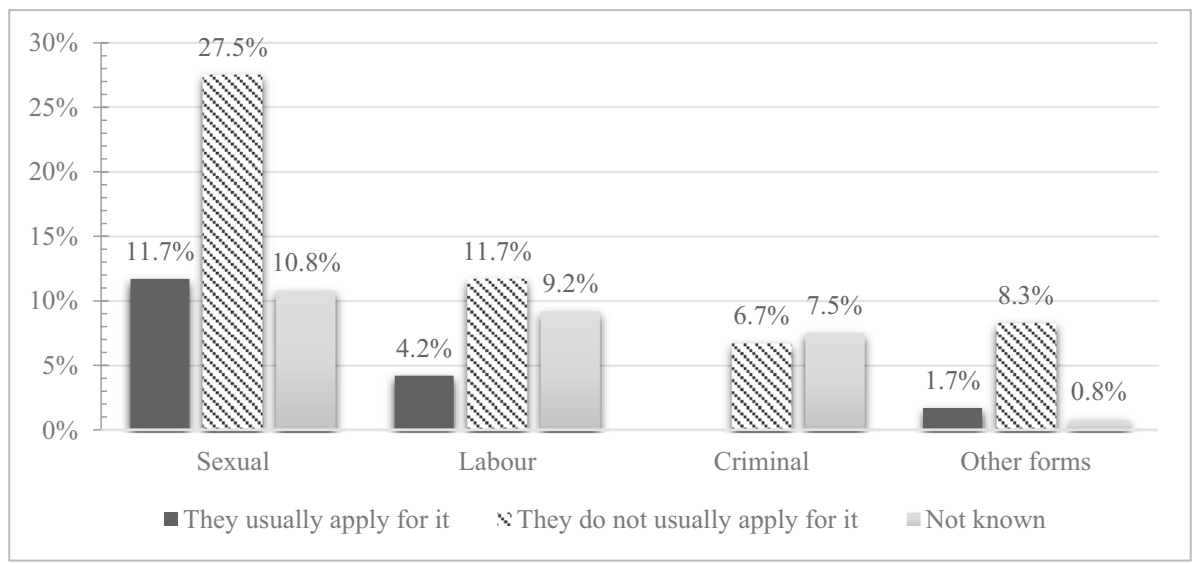

Fig. 10 Frequency with which victims apply for refugee status/subsidiary protection by type of THB 


\section{Discussion and Conclusions}

Despite the limitations derived from a small sample, the predominantly descriptive quantitative analysis of the institutional approach to protecting THB victims undertaken in this paper confirms that the double bias denounced in the Spanish approach to this reality has not been overcome, although the specific struggle against this reality has been being waged for a decade. This renders a large share of the victims invisible, resulting in their lack of protection by the system. Additionally, with regard to those victims who are detected, the research has confirmed that the assistance provided is focused on women victims of sex trafficking who fit the stereotype of undocumented foreigners, with little assistance being provided to other people affected by this process of enslavement.

In a context in which a victim-centred approach to THB - as opposed to the crime-centred approach used in the control of migratory flows - prioritises victim protection over the punishment of criminal conduct, these shortcomings must be addressed for this comprehensive approach to be fully assumed. In this regard, the following proposals, based on the results of this analysis, may help. Although they have been formulated with a view to the Spanish reality, they are likewise applicable to other European countries whose approach to trafficking is as biased and strongly influenced by migratory policy as the one analysed here. That is, taking this analysis as a case study of what a biased national approach to THB may imply, some of the suggestions formulated here might be useful to address the way in which other European countries could deal with this reality in a more effective manner.

First, with regard to the detection of THB victims, more cases are brought to light by the proactive actions of the BUOs involved in the provision of assistance than by complaints filed by the victims themselves or by the people around them. The present research points also to the fact that those bodies more focused on providing assistance in cases of THB, with more training and that are more specialised in the matter, are more effective in detecting victims. This supports the findings of previous studies showing training to be a decisive factor for successful identification (Farrell, 2014; Farrell \& Pfeffer, 2014; Farrell et al., 2020; Kaye et al., 2014; Renzetti et al., 2015; Villacampa \& Torres, 2017, 2018; Warria et al., 2015; Williamson et al., 2020), indicating that more professional training in THB addressing the various manifestations of this reality is needed. However, additionally, in the case of Spain, these results should lead to a rethinking of the exclusive attribution of the power to formally identify and register THB victims to certain police units, which impose immigration regulations and the 2011 Framework Protocol for the Protection of Victims of Trafficking in Human Beings, as the scholarly literature has been calling for (Jiménez \& Tarancón, 2018; Meneses et al., 2015; Villacampa \& Torres, 2017). A multiagency system should be put into place to enable various actors to register THB victims, as is done in the European countries that are most effective in detecting victims. In this regard, the most recent European statistics show that the countries with the most registered victims are those that allow between 3 and 5 different types of actors-immigration officers, NGOs, labour inspectors and border guards, as well as police bodies-to perform this function (European Commission-Migration \& Home Affairs, 2020). Collaboration and intersectoral action are thus key factors to be taken into account in the design of an efficient response to THB, as the specialised literature has also been calling for (DoCarmo, 2020; Erikson \& Larsson, 2020; Ricard-Guay \& Hanley, 2015; Timoshkina, 2020), beginning with the detection of victims itself.

Second, in relation to the assistance provided, this research shows that the implemented mechanisms are mainly targeted at women victims of THB for sexual 
exploitation who fit the stereotype of undocumented migrant, as has been evidenced by the literature (Hacker et al., 2015; Ricard-Guay \& Hanley, 2015, 2020; Torres \& Villacampa, 2017), and are heavily focused on emergency assistance. As a result, other types of victims and of THB are rendered invisible. This is particularly alarming in the case of minors, whose personal circumstances are often unknown and in relation to whom emergency assistance measures are once again applied. This analysis has further confirmed the double bias in the protection measures provided for under immigration law. Although infrequently granted in general, the recovery and reflection period, residence permit on humanitarian grounds and international protection are also granted almost exclusively to victims of THB for sexual exploitation, with disregard for those of trafficking for labour, criminal or other forms of exploitation.

Addressing the shortcomings that, as the results of this analysis show, the victim assistance programme implemented with THB victims has would thus also require abandoning the double bias of preferential assistance for women victims of THB for sexual exploitation who are also undocumented immigrants. At the regulatory level, aspects such as the regulation of victim assistance or the granting of a recovery and reflection period should be separated from immigration law and provided for under legal instruments focused on general victim protection or, if deemed necessary, under a future comprehensive law against trafficking in human beings and slavery. Likewise, immigration law should provide for a way in which an exceptional residence permit can effectively be granted on humanitarian grounds, without making it conditional on the victim's cooperation with law enforcement authorities.

Finally, with regard to the implementation of victim assistance programmes in this field, more should be done to provide for and effectively activate protection measures aimed at victimised groups in addition to sex-trafficked women. Victims of THB for labour exploitation, amongst whom the percentage of men is higher, should also receive attention from the victim assistance system. At the same time, the implemented assistance programmes should not be limited to emergency assistance, but should also include longer-term measures, related to the victim's reintegration and of an occupational nature. It is also especially necessary to meet the assistance needs of minor victims, not only by increasing assistance service providers' level of knowledge of their personal circumstances, but also by applying programmes that, again, are not solely focused on emergency assistance. Amongst other things, efforts should be made to apply measures aimed at monitoring the minor's best interest and ensuring his or her educational integration. Lastly, the protection measures that, due to their very nature, can only be applied to victims who are not legal residents of the country should not only be applied more often and cease to be conditional on cooperation with law enforcement authorities, but should also include as beneficiaries all victims of any form of THB, and not only women who, after the trafficking process, are sexually exploited.

Funding Open Access funding provided thanks to the CRUE-CSIC agreement with Springer Nature. This work was supported by the Spanish Ministry of Science, Innovation and Universities [grant number RTI2018-094686-B-C21].

Availability of Data and Material Data used in this research will be available to the public through the repository of the University of Lleida (https://repositori.udl.cat) once the research project in which it has been carried will have been fully executed (31 December 2022). 


\section{Declarations}

Conflict of Interests The authors declare no competing interests.

Open Access This article is licensed under a Creative Commons Attribution 4.0 International License, which permits use, sharing, adaptation, distribution and reproduction in any medium or format, as long as you give appropriate credit to the original author(s) and the source, provide a link to the Creative Commons licence, and indicate if changes were made. The images or other third party material in this article are included in the article's Creative Commons licence, unless indicated otherwise in a credit line to the material. If material is not included in the article's Creative Commons licence and your intended use is not permitted by statutory regulation or exceeds the permitted use, you will need to obtain permission directly from the copyright holder. To view a copy of this licence, visit http://creativecommons.org/licenses/by/4.0/.

\section{References}

Aronowitz, A. A. (2009). Human trafficking, human misery. The global trade in human beings. Praeger.

Bales, K., Trodd, Z., \& Williamson, A. K. (2009). Modern Slavery: The Secret World of 27 Million People. Oneworld Publications.

Castaño, M. J. (2019). Un estatuto de protección internacional para las víctimas de trata desde la perspectiva del derecho internacional de los derechos humanos. In J. S. Martín Ostos (Ed.), La tutela de la víctima de trata: una perspectiva penal, procesal e internacional (pp. 155-206). JB Bosch Editor.

Castaño, M. J. (2020). Niños y niñas víctimas de explotación o trata”. In Martínez García, C (Dir.), Infancia, pandemia y derechos: treinta años de la Convención sobre los Derechos del Niño en España (pp. 895-913). Cuzur Menor: Thomson Reuters-Aranzadi.

Claro, I. (2019). Una aproximación a la determinación del interés superior de los niños víctimas de trata. Revista del Ministerio de Trabajo, Migraciones y Seguridad Social, 145, 75-96.

Cockbain, E., \& Bowers, K. (2019). Human trafficking for sex, labour and domestic servitude: How do key trafficking types compare and what are their predictors? Crime, Law and Social Change, 72(1), 9-34. https://doi.org/10.1007/s10611-019-09836-7

Cockbain, E., Bowers, K., \& Dimitrova, G. (2018). Human trafficking for labour exploitation: The results of a two-phase systematic review mapping the European evidence base and synthesizing key scientific research evidence. Journal of Experimental Criminology, 14(3), 319-360. https://doi.org/10.1007/ s11292-017-9321-3

Consejo General del Poder Judicial (CGPJ). (2015). Guía de criterios de actuación judicial frente a la trata de seres humanos. http://www.poderjudicial.es/cgpj/es/Poder-Judicial/En-Portada/El-CGPJ-presentauna-Guia-de-criterios-de-actuacion-judicial-para-detectar-e-investigar-la-trata-de-seres-humanos-confines-de-explotacion. Accessed 25 November 2020.

Defensor del Pueblo. (2012). La trata de seres humanos en España: Víctimas Invisibles. https://www.defen sordelpueblo.es/wp-content/uploads/2015/05/2012-09-Trata-de-seres-humanos-en-Espa\%C3\%B1a-v\% C3\%ADctimas-invisibles-ESP.PDF. Accessed 20 November 2020.

DoCarmo, T. E. (2020). Major international counter-trafficking organizations: Adressing human trafficking from multiple directions. In J. Winterdyk \& J. Jones (Eds.), The Palgrave International Handbook of Human Trafficking (pp. 1429-1444). Palgrave Macmillan.

Dwyer, P., Lewis, H., Scullion, L., \& Wale, L. (2011). Forced Labour and UK immigration policy: Status matters? Joseph Rowntree Foundation.

Erikson, J., \& Larsson, O. L. (2020). How platforms facilitate collaboration across organizational boundaries: Fighting human trafficking in Sweden. Policy Sciences, 53, 181-203.

European Commission-Migration and Home Affairs. (2018). Data collection on trafficking in human beings in the EU. https://ec.europa.eu/home-affairs/sites/homeaffairs/files/what-we-do/policies/europeanagenda-security/20181204_data-collection-study.pdf. Accessed 26 November 2020.

European Commission-Migration and Home Affairs. (2020). Data collection on trafficking in human beings in the EU. https://op.europa.eu/es/publication-detail/-/publication/5b93c49f-12a0-11eb-9a54-01aa7 5ed71a1. Accessed 3 January 2022.

Eurostat. (2015). Trafficking in human beings. 2015 edition. https://ec.europa.eu/eurostat/documents/ 3888793/6648090/KS-TC-14-008-EN-1.pdf/b0315d39-e7bd-4da5-8285-854f37bb8801. Accessed 20 November 2020. 
Farrell, A. (2014). Environmental and institutional influences on Police Agency Responses to Human Trafficking. Police Quarterly, 17(1), 3-19. https://doi.org/10.1177/1098611113495050

Farrell, A., \& Pfeffer, R. (2014). Policing human trafficking: Cultural blinders and organizational barriers. The Annals of the American Academy of Political and Social Science, 653(1), 46-64. https://doi.org/ $10.1177 / 0002716213515835$

Farrell, A., Bright, K., De Vries, I., Pfeffer, R., \& Dank, M. (2020). Policing labor trafficking in the United States. Trends in Organized Crime, 23(1), 36-56. https://doi.org/10.1007/s12117-019-09367-6

Fiscalía General del Estado (FGE). (2019). Memoria elevada al Gobierno de S.M. https://www.fiscal.es/ memorias/memoria2019/FISCALIA_SITE/index.html. Accessed 25 November 2020.

García, M. J. (2010). "Bajo el casco de Hades": Menores migrantes no acompañadas como posibles víctimas de trata y su triple invisibilización. Migraciones, 28, 199-223.

Gozdziak, E. M., \& Bump, M. N. (2008). Data and Research on Human Trafficking: Bibliography of Research Based Literature. Georgetown University.

Group of Experts on Action against Trafficking in Human Beings (GRETA). (2013). Report concerning the implementation of the Council of Europe Convention on Action against Trafficking in Human Beings by Spain. First evaluation round. https://rm.coe.int/greta-2013-16-fgr-esp-public-en/16807 1c836. Accessed 20 November 2020.

Group of Experts on Action against Trafficking in Human Beings (GRETA). (2018). Report concerning the implementation of the Council of Europe Convention on Action against Trafficking in Human Beings by Spain. Second evaluation round. https://rm.coe.int/greta-2018-7-frg-esp-en/16808b51e0. Accessed 26 November 2020.

Hacker, D., Levine-Fraiman, Y., \& Halili, I. (2015). Ungendering and regendering shelters for survivors of human trafficking. Social Inclusion, 3(1), 35-51.

Home Office. (2007). Trafficking for the purposes of labour exploitation: A literature review. Home Office.

Iglesias, A. (2013). Trata de mujeres con fines de explotación sexual. Tirant lo Blanch.

International Labour Office (ILO). (2017). Global Estimates of Modern Slavery: Forced Labour and Forced Marriage. https://www.ilo.org/wcmsp5/groups/public/---dgreports/---dcomm/documents/ publication/wcms_575479.pdf. Accessed 20 November 2020.

Jiménez, M., \& Tarancón, P. (2018). Perspectivas de profesionales del tercer sector sobre la intervención con víctimas de trata con fines de explotación sexual. Revista Electrónica de Ciencia Penal y Criminología, 20-25, 1-25.

Jobe, A. (2020). Telling the right story at the right time: Women seeking asylum with stories of trafficking into the sex industry. Sociology, 54(5), 936-952.

Kangaspunta, K. (2007). Collecting data on human trafficking. Availability, reliability and comparability of trafficking data. In E. U. Savona \& S. Stefanizzi (Eds.), Measuring Human. Trafficking Complexities and Pitfalls (pp. 27-36). Sage/Ispac.

Kara, S. (2009). Sex Trafficking. Inside the Business of Modern Slavery. Columbia University Press.

Kaye, J., Winterdyk, J., \& Quarterman, L. (2014). Beyond criminal justice. A case study of responding to human trafficking in Canada. Canadian Journal of Criminology and Criminal Justice, 56(1), 23-48. https://doi.org/10.3138/cjccj.2012.E33

Kelly, L. (2005). "You can find anything you want": A critical reflection on research on trafficking in persons within and into Europe. International Migration, 43, 235-265. https://doi.org/10.1111/j. 0020-7985.2005.00319.x

Laczko, F. (2005). Introduction. In F. Laczko \& E. Gozdziak (Eds.), Data and research on human trafficking: A global survey (pp. 5-16). International Organization for Migration.

Lara, M. A. (2017). El avance irresistible de la concepción de la trata como violación de derechos humanos: luces y sombras de las políticas protectoras de las víctimas en la normativa internacional e interna. In E. Pérez Alonso (Ed.), El Derecho ante las formas contemporáneas de esclavitud (pp. 823-870). Tirant lo Blanch.

Maqueda, M. L. (2009). Prostitución, feminismos y derecho penal. Granada.

Meneses, C., Uroz, J. \& Rúa, A. (2015). Apoyando a las víctimas de trata. Las necesidades de las mujeres víctimas de trata desde la perspectiva de las entidades especializadas y profesionales involucrados. Propuestas para la sensibilización contra la trata. https://violenciagenero.igualdad.gob.es/ violenciaEnCifras/estudios/investigaciones/2015/estudio/Apoyando_Victimas_Trata.htm. Accessed 26 November 2020.

MIPROF. (2018). Les victimes de traite des êtres humains suivies par les associations en France en 2016. https://inhesj.fr/sites/default/files/publications/files/2019-12/ga_48.pdf. Accessed 20 November 2020 . 
Munro, G. (2020). The NGO Response to human trafficking: Challenges, opportunities, and constraints. In J. Winterdyk \& J. Jones (Eds.), The Palgrave International Handbook of Human Trafficking (pp. 1489-1501). Palgrave Macmillan.

National Rapporteur on Trafficking in Human Beings and Sexual Violence against Children (NRTHB). (2018). Victims of Human Trafficking. Periodical Report 2012-2016. Summary. https://www.dutch rapporteur.nl/binaries/FINAL_BNRM-Victims\%20of\%20Human\%20Trafficking-\%20Periodical\% 20Report\%202012-2016_INTERACTIVE_tcm24-353879.pdf. Accessed 25 November 2020.

Obokata, T. (2005). Trafficking of Human Beings as a crime against humanity: Some implications of the international legal system. International and Comparative Law Quarterly, 54(2), 445-457. https:// doi.org/10.1093/iclq/lei005

Obokata, T. (2006). Trafficking in Human Beings from a Human Rights Perspective: Towards a Holistic Approach. Martinus Nijhoff.

Piotrowicz, R. (2018). The European legal regime on trafficking in human beings. In R. Piotrowicz, C. Rijken, \& B. H. Uhl (Eds.), Routledge Handbook of Human Trafficking (pp. 41-51). Routledge.

Renzetti, C. M., Bush, A., Castellanos, M., \& Hunt, G. (2015). Does training make a difference? An evaluation of a specialized human trafficking training module for law enforcement officers. Journal of Crime and Justice, 38(3), 334-350. https://doi.org/10.1080/0735648X.2014.997913

Ricard-Guay, A., \& Hanley, J. (2015). Frontline Responses to Human Trafficking: the coordination of services for victims in Canada. CATHII.

Ricard-Guay, A., \& Hanley, J. (2020). The challenge of addressing both forced labor and sexual exploitation. In J. Winterdyk \& J. Jones (Eds.), The Palgrave International Handbook of Human Trafficking (pp. 287-302). Palgrave Macmillan.

Rijken, C. (2011). Challenges and pitfalls in combating trafficking in human beings for labour exploitation. In C. Rijken (Ed.), Combating Trafficking in Human Beings for Labour Exploitation (pp. 393-423). Wolf Legal Publishers.

Santos, B. (2019). Las víctimas de trata en España. El sistema de acogida de protección internacional. Anuario CIDOB De La Inmigración, 2019, 144-166. https://doi.org/10.24241/AnuarioCIDOBInmi. 2019.144

Scarpa, S. (2008). Trafficking in Human Beings. Oxford University Press.

Skrivankova, K. (2010). Between decent work and forced labour: examining the continuum of exploitation. Joseph Rowntree Foundation Programme Paper.

Timoshkina, N. (2020). Health and Social Service-Based Human Trafficking Response Models. In J. Winterdyk \& J. Jones (Eds.), The Palgrave International Handbook of Human Trafficking (pp. 673706). Palgrave Macmillan.

Torres, N., \& Villacampa, C. (2017). Protección jurídica y asistencia para víctimas de trata de seres humanos. Revista General de Derecho Penal, 27, 1-48.

Tyldum, G., \& Brunovskis, A. (2005). Describing the unobserved: Methodological challenges in empirical studies on human trafficking. In F. Laczko \& E. Gozdziak (Eds.), Data and research on human trafficking: A global survey (pp. 17-24). International Organization for Migration.

United Nations Office on Drugs and Crime (UNODC). (2008). Toolkit to Combat Trafficking in Persons. United Nations.

United Nations Office on Drugs and Crime (UNODC). (2018). Global Report on Trafficking in Persons 2018. https://www.unodc.org/documents/data-and-analysis/glotip/2018/GLOTiP_2018_BOOK_ web_small.pdf. Accessed 20 November 2020.

Van Meeteren, M., \& Hiah, J. (2020). Self-Identification of Victimization of Labor Trafficking. In J. Winterdyk \& J. Jones (Eds.), The Palgrave International Handbook of Human Trafficking (pp. 1605-1618). Palgrave Macmillan.

Van Meeteren, M., \& Wiering, E. (2019). Labour trafficking in Chinese restaurants in the Netherlands and the role of Dutch immigration policies. A qualitative analysis of investigative case files. Crime, Law and Social Change, 72, 107-124. https://doi.org/10.1007/s10611-019-09853-6

Villacampa, C. (2011). El delito de trata de seres humanos. Una Incriminación Dictada desde el Derecho Internacional. Aranzadi-Thomson Reuters.

Villacampa, C. (2012). The European directive on preventing and combating trafficking in human beings and the victim-centric treatment of this criminal phenomenon. European Criminal Law Review, 2(3), 291-317. https://doi.org/10.5235/219174412804816345

Villacampa, C., \& Torres, N. (2017). Human trafficking for criminal exploitation: The failure to identify victims. European Journal on Criminal Policy and Research, 23(3), 393-408. https://doi.org/10. 1007/s10610-017-9343-4 
Villacampa, C., \& Torres, N. (2018). Human trafficking for criminal exploitation: Effects suffered by victims in their passage through the criminal justice system. International Review of Victimology, 25, 3-18. https://doi.org/10.1177/0269758018766161

Villacampa, C., \& Torres, N. (2020). Prevalence, dynamics and characteristics of forced marriage in Spain. Crime, Law and Social Change, 73, 1-21. https://doi.org/10.1007/s10611-019-09881-2

Villanueva, A., \& Fernández-Llébrez, F. (2019). La importancia de los datos de trata de seres humanos. Una aproximación al sistema de recolección de datos de víctimas de trata en España. Deusto Journal of Human Rights, 4, 115-143. https://doi.org/10.18543/djhr-4-2019pp115-143

Warria, A., Neil, H., \& Triegaardt, J. (2015). Challenges in identification of child victims of transnational trafficking. Practice: Social Work in Action, 27(5), 315-333. https://doi.org/10.1080/09503 153.2015.1039974

Weitzer, R. (2012). Sex trafficking and the sex industry: The need for evidence-based theory and legislation. Journal of Criminal Law and Criminology, 101(4), 1337-1370.

Weitzer, R. (2014). New directions in research on human trafficking. The Annals of the American Academy of Political and Social Science, 653(6), 6-24. https://doi.org/10.1177/0002716214521562

Williamson, V., Borschmann, R., Zimmerman, C., Howard, L. M., Stanley, N., \& Oram, S. (2020). Responding to the health needs of trafficked people: A qualitative study of professionals in England and Scotland. Health and Social Care in the Community, 28, 173-181.

Zhang, S. X. (2007). Smuggling and trafficking in human beings. All roads lead to America. Praeger.

Publisher's Note Springer Nature remains neutral with regard to jurisdictional claims in published maps and institutional affiliations. 